\title{
Evaluating Investor-State Dispute System under Ethiopia's Bilateral Investment Treaties: Looking a Workable Roadmap
}

\author{
Endryas Tekalegn (i) \\ Diredawa University, Dire-Dawa, Ethiopia \\ Email: etekalegn@yahoo.com, tekalegnendryas@gmail.com
}

How to cite this paper: Tekalegn, E. (2019). Evaluating Investor-State Dispute System under Ethiopia's Bilateral Investment Treaties: Looking a Workable Roadmap. Beijing Law Review, 10, 115-130. https://doi.org/10.4236/blr.2019.101007

Received: December 22, 2018

Accepted: January 30, 2019

Published: February 2, 2019

Copyright $\odot 2019$ by author(s) and Scientific Research Publishing Inc. This work is licensed under the Creative Commons Attribution International License (CC BY 4.0).

http://creativecommons.org/licenses/by/4.0/

\section{(c) (i) Open Access}

\begin{abstract}
Despite Ethiopia did not yet ratify ICSID convention, many of the bilateral treaties which Ethiopia is a party point to International Centre for Settlement of Investment Disputes and The United Nations Commission on International Trade Law, the problem is how Ethiopia could be coup up with the ICSID community and the ICSID system without the knowledge of the system itself. And what would be the problem if it becomes a member? What does the country lose if it is not a party while it gives consent to the jurisdiction of the center is not clearly articulated? Thus, as investment whether from domestic or foreign sources, is crucial for prosperity, development and robust economies, this writing will scrutinize the bilateral investment treaties signed by Ethiopia and assess the ISDS and arbitral institutions which Ethiopia has consented to resolving investment dispute that may arise between it as a host state and investors of another state, and thereby recommend an arbitral institution which is less evil from the evils.
\end{abstract}

\section{Keywords}

Investor, Bilateral Investment Treaties, Foreign Direct Investment, Investor State Dispute System

\section{Introduction}

True that foreign direct investment has contributed a lot in the creation of jobs and boosting the wealth and economy of recipient countries, it has enhanced way of life, exchange of goods and enabled more and better access to infrastructure of the recipient and transfer of technologies, thus contributing to the sustainable development of these economies thereto (Norris, Honda, et al., 2010) \& 
(UNCTAD, 2011).

True also that an open international investment environment increases the competitiveness of emerging economies by allowing them to serve foreign investors \& markets in order that these investors and markets contribute to the well-being of a country's economy and its citizens, in that, foreign Direct Investment and foreign trade are a pillar in the overall investment $\&$ trade picture even more so in today's globalized and interconnected value chains (Bungenberg, Griebel, \& Hindelang 2011).

Therefore, it can be said that effective and swift investment protection and promotion are more important than ever not only for least developed countries even for developed and developing world. This is because countries that protect investment and those that have pro investment policies and well-established systems of rule of law attract more and higher quality of Foreign Direct Investment.

As foreign Direct investment decisions most of the time involve economic and political risks, such as expropriation, limitations on remittance of income and capital obtained in host state, withdrawal or failure to renew licenses of the investment, arbitrary and discriminatory processes and regulatory procedures by the host state or interference by national courts which often can be biased on foreign investors in which they therefore require guarantees and assurances that they will be treated without discrimination, equitably and fairly with those investors of the host state before investing significant capital and incurring any expenditure in the host country (UNCTAD, 2015).

In order to remedy these uncertainties, international investment agreements including bilateral or even multilateral treaties were designed to confirm basic standards of treatment and try to create safeguards that reduce risks for investors up on facilitating the settlement of investment disputes through well-established, neutral and nonpolitical international arbitration proceedings.

That is to say, as investors need an effective, swift and independent way to implement and enforce commitments therein in the Bilateral Investment Treaties [herein after called BITs] and International Investment agreements [herein after called IIAs]. Investor State Dispute System [herein after called ISDS] fulfills that role in establishing a measure of equilibrium and protection to the disadvantaged position that foreign investors may have in comparison to domestic investors (UNCTAD, 2007). Investor State Dispute System has thus been included in most investment international investment protection agreements including in those bilateral investment treaties to which Ethiopia is a party ${ }^{1}$.

Provisions on investor state dispute settlement (ISDS) have been a core element of international investment agreements (IIAs) and bilateral investment treaties (BITs) for decades and ISDS has played a crucial role as an instrument to

${ }^{1}$ Ethiopia has already signed 32 investment treaties and 22 are ratified \& in force while 10 are not yet in force. And the one signed with Germany in 1964 is terminated. For more on the bilateral treaties signed by Ethiopia, see UNCTAD international investment navigator http://investmentpolicyhub.unctad.org/IIA/CountryBits/67. 
ensure a fair implementation of investment agreements, to enforce the rule of law, to protect companies against arbitrary behavior of states and to guarantee them a fair process (Schill, 2015). Thus, it ensures fair and equitable treatment, access to impartial arbitration and free transfer of capital. As such, it is providing a public good, helps states to attract investment and fosters innovative, high-value development and growth.

Despite this ongoing support of ISDS, it is also undeniable that International investment agreements and investment arbitration in particular are under increased scrutiny.

In 2011 the government Australia vowed that it will no longer include provisions on investor-state dispute settlement (ISDS) in bilateral and regional trade agreements dispute settlement (ISDS) in bilateral and regional trade agreements (Keyla \& Patricia, 2011).

In its resent post, the Department of foreign affairs office states as they will consider ISDS provisions in Free Trade Agreements on a case-by-case basis. And further provides that the Australian Government is opposed to signing up to international agreements that would restrict Australia's capacity to govern in the public interest including in areas such as public health, the environment or any other area of the economy \{.emphasis added $\}^{2}$ (Tienhaara \& Ranald, 2011).

Nicaragua has passed legislation to avoid investment arbitration and Venezuela has signaled its intention to terminate its existing bilateral investment treaties (BITs) including provision for investment arbitration (Appleton, 2010). ${ }^{3}$

Ecuador has rejected the International Centre for Settlement of Investment Disputes [here in after called ICSID] (Diaz, 2009). ${ }^{4}$

China traditionally restricted investor-state provisions in BITs until its more recent emergence as a leading capital exporter (Bjorklund, 2016). And most BITs that China has signed have a provision on the role of their domestic courts in resolving investment disputes.

The Philippines negotiated to exclude investment arbitration in its free trade treaty with Japan in 2007 (Hindelang \& Krajewski, 2016). ${ }^{5}$

Most recently, the European Parliament adopted a resolution supporting the transatlantic trade deal, but rejected a key US demand for an extra-judicial arbitration mechanism or the parliament voted against including investor sate arbitration clause in the proposed TTIP (Robert, 2015). The European Commission's has also proposed investment court either as a self-standing international body or by embedding it into an existing multilateral organization (UNCTAD, 2015).

In September 2012, South Africa gives a notice of termination to the Belgian-Luxembourg Economic Union that it would not renew the existing BIT

\footnotetext{
${ }^{2}$ Australian Government, Department of foreign affairs, Trade investment topics, Investor-State Dispute Settlement, http://dfat.gov.au/trade/topics/pages/isds.aspx.

${ }^{3}$ http://www.ibanet.org/Article/Detail.aspx?ArticleUid=78296258-3B37-4608-A5EE-3C92D5D0B97 9 Last accessed 20/10/2018.

${ }^{4}$ https://www.iisd.org/itn/2009/06/05/ecuador-continues-exit-from-icsid/ last accessed 19/10/2018.
} 
which was set to expire in March 2013 (UNCTAD, 2013).

Besides the South African government has announced that it will not renew twelve other BITs it previously entered into with other European Union member states (Leon, Veeran, \& Warmington 2012). The reason presumably to have a well-established bilateral treaty that could protect its interests.

As per reports, in March 26, 2014 Indonesia is also planning to terminate more than 60 BITs and it has started giving notice of termination. A notice of termination was given to terminate the BIT with the Netherlands as of July 1, 2015 (Bland \& Donnan 2014).

All this ongoing scrutiny over ICSID and IIAs in general and international arbitration in particular, would tell Ethiopia a message to check its bilateral investment treaties and to rethink whether Ethiopia should really take part in the ICSID Investor state dispute system as its bilateral investment treaties are pointing to it.

\section{Overview of Investment Treaties Signed by Ethiopia}

Although bilateral treaty based protection of investment is a recent phenomenon, ${ }^{5}$ the emergence of protection of investment begins with merchant concessions from as early as the tenth century where at this time the merchants were granted concessions allowed to enter Byzantine Ports without paying customs duties (Tietje \& Sipiorski, 2012). Lately the protection has emerged to have a form of trade association concessions from a middle period, and finally Treaties of Friendship, Commerce and Navigation (FCNs) from the late eighteenth century to the mid-twentieth century which finally rests on the bilateral investment treaty signed between Pakistan and Germany which most authors believe it as the first BIT signed between countries for protection investment (Trakman, 2012), (Laborde, 2010) \& (Martha \& Tilahun, 2014).

Six years after the first BIT signed between Germany and Pakistan, in 1966, approximately twenty states ratified the Convention on the Settlement of Investment Disputes between States and Nationals of other States (ICSID Convention), which established ICSID while Ethiopia has signed but not yet ratified the convention. There are almost 3322 agreements from which 2946 are BITs and 376 are TIPs. Among these treaties 2638 were in force at according to the report of UNCTAD (UNCTAD, 2018).

As a party to this contemporary world, Ethiopia has also signed investment protection treaties with various countries. According to the data provided on UNCTAD website, Ethiopia has signed 34 BITS from which 21 treaties are in force and also signed 6 treaties with investment provisions and 10 multilateral investment related instruments (UNCTAD 2013) ${ }^{6}$. But the author suspects more unrecorded treaties by UNCTAD as the country is seen in signing trade and in-

${ }^{5}$ In 25 November 1959, West-German Germany entered into the first ever bilateral investment treaty (BIT) with Pakistan to protect German investments in Pakistan. ${ }^{6}$ https://investmentpolicyhub.unctad.org/IIA/CountryIris/67\#iiaInnerMenu Last Accessed 30/11/2018. 
vestment treaties on news stream with various countries. In the treaty which Ethiopia has signed with United Kingdom ${ }^{7}$, Algeria $^{8}$, China, ${ }^{9}$ Denmark, ${ }^{10}$ Iran, ${ }^{11}$ Israel, ${ }^{12}$ Austria ${ }^{13}$, Belgian-Luxemburg economic Union, ${ }^{14}$ Finland, ${ }^{15}$ France, ${ }^{16}$ Germany ${ }^{17}$, Kuwait, ${ }^{18}$ Spain, ${ }^{19}$ Sudan, ${ }^{20}$ Sweden, ${ }^{21}$ Tunisia, ${ }^{22}$ Turkey, ${ }^{23}$ Yemen, ${ }^{24}$ Netherland, ${ }^{25}$ there is a provision of ISDS in that the dispute between investor and the country (host state) can be settled at ICSID.

It should be noted here that though each bilateral treaty which Ethiopia has signed with countries points to ICSID, the choice is left for the investor and there are criteria's whereby the case could be referred to ICSID under every bilateral treaty.

Majority of the treaties provides that the case can be submitted to ICSID where both the investor's state and the host state are contracting parties and/or/under the rules governing the Additional Facility for the Administration of Proceedings by the Secretariat of the Centre. While the treaty signed with United Kingdom, France and Finland seems that it directly choses ICSID as the

${ }^{7}$ See Article 8/3/a/ of the treaty between Government of the United Kingdom of Great Britain and Northern Ireland and the Government of the Federal Democratic Republic of Ethiopia.

${ }^{8}$ See Article 9/3/a/ of the treaty between The Government of the People's Democratic Republic of Algeria and the Government of the Federal Democratic Republic of Ethiopia.

${ }^{9}$ See Article 9/3/ of the treaty between The Government of the Federal Democratic Republic of Ethiopia and the Government of the People's Republic of China.

${ }^{10}$ See Article 9/2/a/ of the treaty between The Federal Democratic Republic of Ethiopia and the Kingdom of Denmark.

${ }^{11}$ See Article 12/2/ii/ of the treaty between The Government of the Federal Democratic Republic of Ethiopia and the Government of the Islamic Republic of Iran.

${ }^{12}$ See Article 8/2/c/ of the treaty between The Government of the Federal Democratic Republic of Ethiopia and the Government of the State of Israel.

${ }^{13}$ See Article 12/1/c/i/ of the treaty between the Republic of Austria and The Government of the Federal Democratic Republic of Ethiopia.

${ }^{14}$ See Article $11 / 3$ / of the treaty between The Government of the Federal Democratic Republic of Ethiopia and Belgian-Luxemburg economic Union.

${ }^{15}$ See Article 9/1/b/ of the treaty between The Government of the Republic of Finland and the Government of the Federal Democratic Republic of Ethiopia.

${ }^{16}$ See Article 9/b/ of the treaty between The Government of the Federal democratic Republic of Ethiopia and the Government of the Republic of France.

${ }^{17}$ See Article 11/2/c/ of the treaty between The Federal Republic of Germany and the Federal Democratic Republic of Ethiopia.

${ }^{18}$ See Article 9/3/a/ of the treaty between the Federal democratic Republic of Ethiopia and the state of Kuwait.

${ }^{19}$ See Article 11/2/c/ of the treaty between The Federal Democratic Republic of Ethiopia and the Kingdom of Spain.

${ }^{20}$ See Article 9/2/b/ of the treaty between The Government of the Federal Democratic Republic of Ethiopia and the Government of the Republic of the Sudan.

${ }^{21}$ See Article 8/2/i/ of the treaty between The Government of the Kingdom of Sweden and the Government of the Federal Democratic Republic of Ethiopia.

${ }^{22}$ See Article $7 / 3 /$ of the treaty between The Government of the Federal Democratic Republic of Ethiopia of and the government of the Republic of Tunisia.

${ }^{23}$ See Article $7 / 2 / \mathrm{b} /$ of the treaty between The Republic of Turkey and the Federal Democratic Republic of Ethiopia.

${ }^{24}$ See Article 9/b/ of the treaty between The Government of the Federal Democratic Republic of Ethiopia and the Government of the Republic of Yemen.

${ }^{25}$ See Article 9/2/b/ of the treaty between The Federal Democratic Republic of Ethiopia and the Kingdom of the Netherlands. 
institution for settlement of investment disputes between an investor where Ethiopia is a hose state and the country.

Bilateral treaties signed with countries such as the Government of the Islamic Republic of Iran and the government of the Republic of Tunisia provides ICSID as an institution to settle dispute between such countries if both disputants are contracting parties to ICSID and doesn't provide the option of additional facility rules as other bilateral treaties did. While the treaty with China limits the claim to be submitted to ICSID only to disputes of expropriation. And the treaty with Russia completely ignores ICSID. ${ }^{26}$

An author noted here that in the report of the Executive Directors made at the adoption of the ICSID convention it is provided that consent to be a party to the convention need not be provided in a single document, (Ghaffari, 2011) Rather can be manifested from contractual agreement made between the host state and foreign investor, treaties signed by the home and host states, or in the unilateral offer by the host state in its national legislation. ${ }^{27}$

This shows that ICSID will have jurisdiction despite the disputants are not contracting parties so long as the states gives their consent through multilateral or bilateral treaty or unilateral offer by host state in its national legislation to be tried by the rules of ICSID convention.

However, despite many of the bilateral treaties which Ethiopia is a party point to ICSID; Ethiopia is not yet a member of ICSID convention. And the problem is how Ethiopia could coup up with the ICSID community and the ICSID system without the knowledge of the system itself. Thus, Should Ethiopia is party to ICSID? What would be the problem if it becomes a member? What does the country loses if it is not a party while it gives consent to the jurisdiction of the center at least through the additional facility rules?

This is not clearly studied yet, and in fact, it must be and the cost \& benefit of being a party should be analyzed in order to decide what the position of Ethiopia should be; given the fact that there are countries that has denounced ICSID and there are countries that are subjecting investment disputes to domestic courts and there are still others who are using the ICSID for few claims as opposed to all claims by the investor and also countries such as the EU are pushing for the idea of an investment court.

Given the need of the country to attract investors and the need of investors to settle their dispute at international arbitration, comparing international arbitration institutions at least ICSID \& UNICITRAL (as almost all BITs to which Ethiopia is a party point to ICSID and UNICITRAL) and choosing the less evil among the evils is something that is helpful for the country.

In doing so, while providing international arbitration as dispute resolution mechanism under its BITS, the country may bargain to provide only UNICITRAL

\footnotetext{
${ }^{26}$ See Article 8 of the treaty with the Russian Federation and Ethiopia.

${ }^{27}$ Sometimes host states may unilaterally enact a law that regulates investment in the state thereby any dispute that may arise therein can be settled at ICSID or other international Arbitral institution, this in effect results in giving consent to that international arbitral institution.
} 
and other institutions than ICSID had the difference between arbitration at ICSID according to the ICSID convention or through its additional facility rules or/and UNICTRAL rules at ad hoc arbitral institution is clearly studied and the negotiators of the country have understood the effect of including ICSID and under the BITs to which Ethiopia is a party.

Therefore, at least studying the effect of including ICSID as a mechanism of dispute resolution under BITs of the country is something crucial and necessary to effectively defend future claims, if any, brought against the country.

\section{Choosing the Less Evil for Good Sake}

If it is said that the dispute between foreign investor and Ethiopia can be settled through arbitration (be it at ICSID, through UNICITRAL rules by ad hoc arbitrators or any other international arbitration tribunal), studying the relationship between domestic courts (Bronckers, 2015) and arbitration tribunals is an indispensible part of investor sate dispute system.

So why developing countries and least developed like Ethiopia ${ }^{28}$ (The World Bank, 2018) opts to choose ICSID in their bilateral investment treaties is a question that everyone asks and the answer is as simple as the question itself.

From the point of view of attracting investment and investors the host state like Ethiopia believed not to have the power to bargain the contents of investment treaties. This is because the investor's home country always put the investment and investor's agenda at the top of the table than any other issues. And host countries as their top agenda is attracting the investment, they are not in a position to sit down and bargain on each and every points of the treaty. Sometimes the negotiators in the treaty may not have sufficient knowledge in the filed as though they were in the country of the investor. Authors such as Blyschak and Guzman argue that developing states do not feel that they have been enjoying their fair share of return on the bargain (Blyschak 2008) \& (Guzman, 1997).

If that is the case, rather than accepting all the terms and conditions of agreement in the treaty proposed by capital exporting country (home state), a systematic way of accepting the terms shall be adopted by the negotiators of capital importing (often developing and least developed countries) or host states.

This points the burden on the negotiators of host state to have well equipped knowledge in the field they are bargaining and systematic way of excluding the terms and conditions of the treaty which might endanger the host state.

Thus, before bargaining on the provisions of ISDS under any bilateral investment treaty Ethiopian negotiators shall be prudent enough and capable of distinguishing the difference between arbitration at ICSID and arbitration through other Arbitral institutions.

In fact Latin American countries such as Ecuador consider that ICSID is biased towards wealthy Western states. ${ }^{29}$ And it is also said that 'a losing party to

${ }^{28}$ Still Ethiopia is one of the least developed countries as provided by the World Bank in 2018. See https://data.worldbank.org/region/least-developed-countries:-un-classification Last Accessed $18 / 11 / 2018$. 
dispute in most of the time volunteers to execute the judgment of the center with the hope that it doesn't strain its relationship with the World Bank. As ICSID being an affiliate of the World Bank, refusing to execute the judgment of the center could jeopardize the chance to get loans easily as those states which show cooperation' (Shihata, 1986). The perception that ICSID arbitration empowers both old and new wealthy countries at the expense of poorer countries is supported by the criticism that the ICSID is a witting or unwitting party to a world order dominated by institutions and processes that are directed at wealth enhancement, not wealth sharing (Trakman, 2012).

But that fact is not something this writing wants to look for rather the very criticism against raised against ICSID and to look the way forward. Thus, among other things; the main criticism sought against ICSID is unlike in non-ICSID arbitration (through The United Nations Commission on International Trade Law [here in after called UNICITRAL] rules or ICSID Additional Facility rules) where court intervention is possible dependent on factors such as the connection the case has with that particular country, the types of measures requested, the place of arbitration, the nationality of the parties, the law governing the arbitration, the existence of a valid arbitration agreement, protection of public interest etc., under ICSID, the arbitral system is self-contained; in that, ICSID awards are final and the role of courts is limited to enforcement of the award and other supports sought by the tribunal in the process of arbitration such as order for summons of witnesses. Besides, although there is a procedure for annulment provided for reasons stipulated Article 52 the ICSID convention, the power to annul awards is vested on the ICSID annulment committee not local courts or the courts of the seat of Arbitration.

To be more clear, as the ICSID Additional Facility was mainly created to facilitate disputes which are outside the jurisdiction of ICSID in view of the requirements of Article 25 of the ICSID Convention the Additional Facility merely administers the framework with reference to the Additional Facility Rules and it is in no other way connected to the ICSID Convention thereby the awards rendered under the Facility will not be getting the advantages of the ICSID Convention on recognition, enforcement and compliance of awards.

Similarly, although Ad hoc arbitral awards are final in theory, arbitration by ad hoc tribunal through UNCITRAL model law and arbitration rules gives the power to set aside the award for the court that has jurisdiction over the place where tribunal sat in accordance with Article 34 of UNCITRAL model law or for the court where the investor seeks enforcement as the time of enforcement domestic courts may refuse recognition of the award in accordance with the grounds set forth for refusal by the New York convention for enforcement of

\footnotetext{
${ }^{29}$ President Raphael Correa of Ecuador stated that "the ICSID was established by, and arguably in the interest of, wealthy countries and their investors abroad." These concerns of developing states are reflected in their collective attempts to protect "their" New International Economic Order through the General Assembly of the UN, through supporting a Charter of Economic Rights and Duties of States and a Declaration on the Permanent Sovereignty of States over Natural Resources.
} 
foreign awards. To this effect as Ethiopia is not yet party to the New York convention, the provisions for of the civil procedure code for recognition and enforcement of foreign award will apply and thereby Ethiopian courts may refuse to enforce the award for reasons stipulated under Article 458 of the civil procedure code.

So, for one thing or another, countries such as Ethiopia should play tricky games on choosing which investment arbitration institution is pro-least developed countries as they may be un able to compete with wealthy countries of the west (who have money \& skilled man power in each field of dispute) to equally litigate in the arbitration process. This is because on the one hand these countries need to attract investment while on the other hand investment exporting countries bargain to have well established system that could protect the investment and their investors. Thus, the tricky game of card here is to at least choose the less evil from the evils.

\section{Analyzing BITs Signed by Ethiopia}

As the policy of the Government of Ethiopia is pro investment, Ethiopia is Africa's third largest recipient of foreign direct investment in the year 2014 (Tsegaye, 2014) and second largest recipient of foreign direct investment in the year $2017 .{ }^{30}$ This shows that Ethiopia is becoming a destination of foreign direct investment and in the process of this ever growing investment in the country, dispute is inevitable. And this makes things critical in that; assessing the ISDS of the country under BITs which Ethiopia is a party is unavoidable task so as the country not to be swallowed by a storm of claims from foreign investors.

Taking this as a guise, the writer undertakes rough investigation on the treaties signed by Ethiopia as found on the UNTACD web. As said above, Ethiopia is said to have signed 34 BITs and 14 of these where either terminated or not in force. From those treaties in force the writer selects the treaty signed with UK, France and Finland as it have problems that could endanger the country in the process of resolving the dispute with investors of such states.

To begin, the treaty signed with United Kingdom of Great Britain and Northern Ireland and Ethiopia was signed in Addis Ababa on $19^{\text {th }}$ of November 2009 and it shall remain in force for a period of ten years. ${ }^{31}$ The provision that deals about the settlement of investment dispute between the investor and host state is provided under Article 8 of the treaty. Article 8/3/ of the treaty provides specifically about the right of the investor for international Arbitration. It provides:

3. Where the dispute is referred to international arbitration, the national or company and the Contracting Party concerned in the dispute may agree to refer the dispute either to: ${ }^{32}$

\footnotetext{
${ }^{30}$ See, world investment report of 2018, UNCTAD/PRESS/PR/2018/018 Geneva, Switzerland, (06 June 2018) http://unctad.org/en/pages/PressRelease.aspx?OriginalVersionID=461, Last accessed $16 / 8 / 2018$.

${ }^{31}$ See the last statement of the treaty between Government of the United Kingdom of Great Britain and Northern Ireland and the Government of the Federal Democratic Republic of Ethiopia.
} 
1) The International Centre for the Settlement of Investment Disputes (having regard to the provisions, where applicable, of the Convention on the Settlement of Investment Disputes between States and Nationals of other States, opened for signature at 9 Washington DC on 18 March 1965 and the Additional Facility for the Administration of Conciliation, Arbitration and Fact-Finding Proceedings); or

2) The Court of Arbitration of the International Chamber of Commerce, or

3) An international arbitrator or ad-hoc arbitration tribunal to be appointed by a special agreement or established under the Arbitration Rules of the United Nations Commission on International Trade Law. If after a period of three months from written notification of the claim there is no agreement to one of the above alternative procedures, the dispute shall at the request in writing of the national or company concerned be submitted to arbitration under the Arbitration Rules of the United Nations Commission on International Trade Law as then in force. The parties to the dispute may agree in writing to modify these Rules.

Accordingly, if a dispute arises between British \& Northern Ireland Investor and Ethiopia and unless the contract between the investor and Ethiopia provides other mechanisms of dispute resolution than international arbitration or the investor has not submitted to the competent court in accordance with Article $8 / 1 / 2 /$ of the treaty, the investor can submit its claim to any of the arbitration system provided under Article $8 / 3$ / of the treaty.

From the reading of Article 8/3/ where British \& Northern Ireland investor wishes to refer its claim to international arbitration, it provides only a requirement of agreement between the investor and the country.

So, the question is since the definition of investment is too open (UNCTAD, 2010) to protect every asset of foreign national as investment; are investment Agency officers and local \& regional administrators who are greedily looking for investment really consider the contract concluded with British \& Northern Ireland investors? Did they really consider the Investor state dispute resolution provisions in the contract and exclude ICSID or include a statement to be tried at ICSID "where both Contracting Parties are members to the Convention"? The writer suspects otherwise.

Similarly, the other treaty that the writer selects as having problem in resolving investor state dispute is the treaty signed between France and Ethiopia. The treaty between the government of the Federal democratic Republic of Ethiopia and the Government of the Republic of France was signed in Paris on 25th June 2003 and shall be in force for an initial period of twenty years. It shall remain in force thereafter, unless one of the Contracting Parties gives one year's written notice of termination. ${ }^{33}$

The provision that deals about the settlement of investment dispute between ${ }^{32}$ [emphasis added] this provision of the treaty put everything on the contract to be concluded between the investor and the country.

${ }^{33}$ See Paragraph 2 of Article 12 of the treaty between The Government of the Federal democratic Republic of Ethiopia and the Government of the Republic of France. 
the investor and host state is provided under Article 9 of the treaty. Article 9/b/, /c/ \& /d/ of the treaty provides specifically about the right of the investor for international Arbitration. It provides:

2) the International Center for Settlement of Investment Disputes, for settlement by arbitration or conciliation under the Convention on the Settlement of Investment Dispute between States and Nationals of Other States opened for signature in Washington on March 18, 1965 if the Contracting Party, party to the dispute, has acceded to it, or [emphasis added].

3) the International Center for Settlement of Investment Disputes under the Rules Governing the Additional Facility for the Administration of Proceedings by the Secretariat of the Center (Additional Facility Rules); or

4) an international ad-hoc arbitral tribunal under the Arbitration Rules of the United Nations Commissions on International Trade law (UNCITRAL).

As different from other treaties to which Ethiopia is a party, the treaty between France and Ethiopia creates clear ambiguity and vagueness in the interpretation of Article 9/b/ last statement which provides that a dispute can be submitted to ICSID "if the Contracting Party, party to the dispute, has acceded to it". It doesn't use the statement "where both Contracting Parties are members to the Convention" as though they were in other bilateral treaties or it doesn't even say "contracting parties".

So by virtue of this provision if a French investor wants to bring its case to ICSID it is enough for it to show that French as contracting party or as a party to dispute through its national (citizen) is acceded to the convention. ${ }^{34}$

The same line of argument can be reached out for Finland as well. Looking at a treaty signed between Finland and Ethiopia the treaty was signed at Addis Ababa on $23^{\text {rd }}$ of February 2006 to remain in force for 20 years. ${ }^{35}$ The provision that deals about the settlement of investment dispute between the investor and host state is provided under Article 9 of the treaty.

Accordingly, if a dispute arises between an investor from Finland and Ethiopia and unless the contract between the investor and Ethiopia provides other mechanisms of dispute resolution than international arbitration; or the investor has not submitted to the competent court in accordance with Article 9/2/a/ of the treaty, or not settled their dispute amicably, the investor can submit its claim to any of the arbitration system provided under Article 9/2/b, c, d \& e/ of the treaty.

These provisions provide:

2) arbitration by the International Centre for Settlement of Investment Disputes (ICSID), established pursuant to the Convention on the Settlement of Investment Disputes between States and Nationals of other States, opened for signature at Washington on 18 March 1965 (hereinafter referred to as the "Cen-

\footnotetext{
${ }^{34}$ France has signed the ICSID convention in Dec. 22, 1965 deposited the ratification in Aug. 21, 1967 and the convention entered in to force on Sep. 20, 1967.

${ }^{35}$ See Article 17/2/ of the treaty between The Government of the Republic of Finland and the Government of the Federal Democratic Republic of Ethiopia.
} 
tre"), if the Centre is available; or [emphasis added]

3) arbitration by the Additional Facility of the Centre, if only one of the Contracting Parties is a signatory to the Convention referred to in subparagraph (2) of this paragraph; or (4) an ad hoc arbitration tribunal to be established under the Arbitration Rules of the United Nations Commission on International Trade Law (UNCITRAL); or

5) any other previously accepted ad hoc arbitration tribunal.

As emphasized here in above, the treaty between Ethiopia and Finland also allows the investor to bring its claim at ICSID if the center is available. The statement which says if "if the Centre is available" is unclear and creates ambiguity whether it wants to say that if both parties are party to ICSID or wants to say that the investor and host state has chosen ICSID as an arbitral institution to resolve their future and existing disputes.

What will happen if for example regional investment bureaus has signed a memorandum of understanding or a contract with investors of foreign nationals and in that contract they have agreed to settle their dispute at ICSID, will such contract have any effect for ICSID to assume jurisdiction alleging that the country is consented to the center by virtue of such contract and the above provision? This is in fact chaotic for the country.

\section{Looking for a Workable Road Map}

True that a poor man who also doesn't know the working language of the court cannot equally bargain with the rich and protect its interest in local court ligation. Similar to this, Ethiopia cannot equally litigate before international arbitration tribunals with giant investors and transnational corporations who own years of capital of the country.

It is also true that that the country should work hard to attracting investors but this couldn't happen in this world where everything is interconnected and investment is surely essential for any state's prosperity without protecting investment itself.

So, given the major criticism that encompasses ICSID such as the perceived bias of the ICSID towards wealthy Western nations (the North) and their investors, and the fear that such any hostility towards ICSID could endanger an access to credit claim by poor nations (the south) from World Bank on the one hand and the need to attract investors and Foreign direct investment by poor countries such as Ethiopia on the other with due notice of the effect of the knowledge of investment arbitration culture by poor countries, proper handling of investor state dispute system under BITs is a crucial aspect that should be given serious focus.

As there are ongoing criticism as discussed above including the pressure on developing and poor countries to resort assistance and legal advice \& representation from extremely expensive foreign law firms; the non-commercial interests that could endanger the host state and its inhabitants as in the case of health or environmental concerns which ICSID does not given sufficient attention; a lack 
of transparency in the process of arbitration by arbitration panels; the suspicion that there is a shadow of arbitrator bias in favor of the investor reaching different conclusions and results on similar issues and legal claims; (Fiezzoni, 2011) the absence of an appeals process, but only a limited annulment procedure by ICSID itself; failure to consider the situations of massive economic downturns; (Boeglin, 2013) its failure to provide a viable alternative to national courts resolving investment disputes between states and foreign investors and total exclusion of Courts even after awards should let countries such as Ethiopia to systematically answer the need of ISDS in BITs and embark to other investor state dispute system which are pro south whereby at least countries of the south could have access to consider awards of pro-Western investment arbitration centers.

Thus Ethiopia should take effective steps in terminating the existing bilateral investment treaties with countries selected as a reference under this writing. Especially as the treaty between Ethiopia and Government of the United Kingdom of Great Britain and Northern Ireland is not yet enforce the House of People's Representatives shall consider this truth thereby question the Executive and reject such treaty as it could endanger the country by giving an opportunity for submission of cases to ICSID even without being member to this convention. This is because, from the reading of Article 8/3/ where British \& Northern Ireland investor wishes to refer its claim to international arbitration, it provides only a requirement of agreement between the investor and the country which in fact this very easy to be done as investors can do it given the need of the local officials to treat investors and the absence of adequate man power in the field of investment contracts.

Similarly, in giving notice of termination, the concerned authorities shall manage it effectively in a manner of treating investors and host states; as such notice of termination might trigger obstacles in the flow of investments. So, this can be arranged in providing joint investment discussion with the host state so as to smooth up the relationship between those states which thereby create good relation before sending the message of termination.

Once the discussion is made and things become smooth, the concerned authorities shall send letter of termination of the treaty and at the same time keep the words in the treaty so strongly until the time in the notice of termination elapses so as to increase confidence of the host state. Besides, the authorities shall choose best investment and arbitration negotiators to come up with viable and workable treaty that could exclude ICSID in one way or another from those treaties which Ethiopia will be party or use appropriate wordings on the application of those treaties so as the ICSID convention and ICSID arbitration applies only where both contracting parties are party to ICSID convention as Ethiopia is not still party to the convention and in fact it shouldn't be party to it.

\section{Concluding Remarks and the Way Forward}

To sum up, it is discussed above that the south shall attract investors and investments as foreign investment, robust economic growth of host states. Al- 
though attracting investment is something crucial for development and robust economic growth, investment treaties which least developed counties signs shall be such that couldn't endanger the country itself.

In this regard, a discussion made above regarding Bilateral investment treaties which Ethiopia has signed with different countries so as to explain how provisions of ISDS incorporated in the treaties and assess whether these treaties negotiated and signed in a way that could protect the interest of the country regarding investor state dispute in the treaty.

In so doing, taking the treaty signed with Ethiopia and British \& Northern Ireland, Finland \& France as an example, the writer argued that the provisions of investor state dispute system in this treaty articulated in a way that could endanger the interest of the country especially the poor and least developed such as Ethiopia.

Thus, the writer argued that in looking for Foreign Direct investment countries such as Ethiopia shall not be affected by dispute resolution system where they cannot engage and bargain in with multinational corporations and giant investors merely because they are in need of investment. So, the middle path that could ascertain the need of protection of investment by investors \& home states, and the need of host countries to attract investment can be tolerated by those ISDS which are pro South (the poor) especially the UNCITRAL and ICSID Additional Facility rather than choosing ICSID as a place of Arbitration. In doing so, the UNCITRAL rule or even ICSID additional Facility rule gives option for countries to review at least at the time of enforcement but not awards of ICSID. So the negotiators of investment treaties shall choose the less evil for good sake although international arbitration with Giant Corporation by itself is expensive for poor countries such as Ethiopia.

\section{Conflicts of Interest}

The author declares no conflicts of interest regarding the publication of this paper.

\section{References}

Appleton, S. (2010). Latin American Arbitration: The Story behind the Headlines. International Bar Association.

http://www.ibanet.org/Article/Detail.aspx?ArticleUid=78296258-3B37-4608-A5EE-3C9 2D5D0B979

Bjorklund, A. K. (2016). Yearbook on International Investment Law and Policy 2014-2015. Oxford: Oxford University Press.

Bland, B., \& Donnan, S. (2014). Indonesia to Terminate More than 60 Bilateral Investment Treaties Multinationals Accused of Bullying Developing Countries. Financial Times. https://www.ft.com/content/3755c1b2-b4e2-11e3-af92-00144feabdc0

Boeglin, N. (2013). Criticism, Withdrawal and the Search for Alternatives. https://www.brettonwoodsproject.org/wp-content/uploads/2013/12/At-Issue-ICSID.pd f

Bronckers, M. (2015). Is Investor-State Dispute Settlement (ISDS) Superior to Litigation before Domestic Courts?: An EU View on Bilateral Trade Agreements. Journal of In- 
ternational Economic Law, 18, 655-677. https://doi.org/10.1093/jiel/jgv035

Bungenberg, M., Griebel, J., \& Hindelang, S. (2011). International Investment Law and EU Law. Berlin Heidelberg: Springer-Verlag.

https://doi.org/10.1007/978-3-642-14855-2

Diaz, F. C. (2009). Ecuador Continues Exit from ICSID. Investment Treaty News, International Institute for Sustainable Development. https://www.iisd.org/itn/2009/06/05/ecuador-continues-exit-from-icsid/

Fiezzoni, S. K. (2011). The Challenge of UNASUR Member Countries to Replace ICSID Arbitration. Beijing Law Review, 2, 134-144. https://doi.org/10.4236/blr.2011.23014

Ghaffari, P. (2011). Jurisdictional Requirements under Article 25 of the ICSID Convention: Literature Review. The Journal of World Investment \& Trade, 12, 605. https://doi.org/10.1163/221190011X00292

Guzman, A. T. (1997). Why LDCs Sign Treaties That HurtThem: Explaining the Popularity of Bilateral Investment Treaties. Virginia Journal of International Law, 38, 639.

Laborde, G. (2010). The Case for Host State Claims in Investment Arbitration. Journal of International Dispute Settlement, 1, 97-122. https://doi.org/10.1093/jnlids/idp008

Leon, P., Veeran, J., \& Warmington, E. (2012). South Africa: South Africa Declines to Renew Bilateral Investment Treaties with European Union Member States. http://www.mondaq.com/southafrica/x/199586/international+trade+investment/South + Africa+Declines + To+Renew + Bilateral+Investment + Treaties + With+European + Unio $\underline{\mathrm{n}+\text { Member+States }}$

Martha, B. H., \& Tilahun, E. K. (2014). Rethinking Ethiopia's Bilateral Investment Treaties in light of Recent Developments in International Investment Arbitration. Mizan law Review, 8, 123.

Norris, E. D., Honda, J., Lahreche, A., \& Verdier, G. (2010). FDI Flows to Low Income Countries: Global Drivers and Growth Implication. IMF Working Paper WP/10/132.

Robert, A. (2015). European Parliament Backs TTIP Rejects ISDS.

http://www.euractiv.com/section/global-europe/news/european-parliament-backs-ttiprejects-isds/

Schill, S. W. (2015). Reforming Investor-State Dispute Settlement (ISDS): Conceptual Framework and Options for the Way forward, E15 Initiative. Geneva: International Centre for Trade and Sustainable Development (ICTSD) and World Economic Forum.

Shihata, I. F. I. (1986). The Settlement of Disputes Regarding Foreign Investments: The Role of the World Bank with Particular Reference to ICSID and MIGA. Arab Law Quarterly, 1, 265-279. https://doi.org/10.2307/3381749

The World Bank (2018). Least Developed Countries: UN Classification. https://data.worldbank.org/region/least-developed-countries:-un-classification

Tienhaara, K., \& Ranald, P. (2011). Australia's Rejection of Investor-State Dispute Settlement: Four Potential Contributing Factors. Investment Treaty News.

Tietje, C., \& Sipiorski, E. (2012). International Investment Law and Soft Law. In A. K. Bjorklund, \& A. Reinisch (Eds.). USA: Edward Elgar Publishing Inc.

Trakman, L. E. (2012). The ICSID under Siege. Cornell International Law Journal, 45, 619.

Tsegaye, A. (2014). Ethiopia: Africa's Third Largest Recipient of Foreign Direct Investment. Addis Fortune, 15.

http://addisfortune.net/articles/ethiopia-africas-third-largest-recipient-of-foreign-direc t-investment/ 
UNCTAD (2007). Investor-Sate Dispute Settlement and Impact on Investment Rule Making. New York and Geneva: United Nations.

UNCTAD (2010). Latest Developments in Investor-State Dispute Settlement IIA Issue Note No. 1 (2010). International Investment Agreements. New York and Geneva: United Nations.

UNCTAD (2011). Best Practices in Investment for Development How to Prevent and Manage Investor-State Disputes: Lessons from Peru, Investment Advisory Series-Series $B$, Number 10. S. New York and Geneva: United Nation.

UNCTAD (2013). Investment Policy Hub. https://investmentpolicyhub.unctad.org/IIA/CountryIris/67\#iiaInnerMenu

UNCTAD (2013). World Investment Report 2013: Global Value Chains: Investment and Trade for Development. Geneva: United Nations Publication.

UNCTAD (2015). World Investment Report (WIR15), Reforming International Investment Governance. http://unctad.org/en/PublicationsLibrary/wir2015_en.pdf

UNCTAD (2018). IIA Issues Note, Recent Development in the International Investment Regime. https://unctad.org/en/PublicationsLibrary/diaepcbinf2018d1_en.pdf 